\title{
Performance Matters
}

\section{On the Record: Sissieretta Jones and Black Feminist Recording Praxes}

\section{Kristin Moriah}

Volume 6, Number 2, 2020

Sound Acts, Part 1

URI: https://id.erudit.org/iderudit/1075797ar

DOI: https://doi.org/10.7202/1075797ar

See table of contents

Publisher(s)

Institute for Performance Studies, Simon Fraser University

ISSN

2369-2537 (digital)

Explore this journal

Cite this article

Moriah, K. (2020). On the Record: Sissieretta Jones and Black Feminist

Recording Praxes. Performance Matters, 6(2), 26-42.

https://doi.org/10.7202/1075797ar
Article abstract

In this article, I examine how Sissieretta Jones (frequently described as America's first Black superstar, among other superlatives) strategically leveraged her European performance reviews in order to increase her listenership and wages in the United States. Jones toured Europe for the first (and only) time from February until November in 1895. According to clippings that she provided to African American newspapers, the singer performed at the renowned Winter Garden in Berlin for three months. Sissieretta Jones also claimed that she performed for Wilhelm II, the last German Emperor and King of Prussia, at his palace and was subsequently presented with an elaborate diamond brooch for her performance. Afterward, the singer told the African American newspaper the Indianapolis Freeman that she would like to live in Europe permanently. Her biographers frequently cite the success of this trip and its symbolic importance for African Americans. And yet, evidence of these events in the archives of major German newspapers is elusive and contradictory at best, if it exists at all. Nevertheless, after the much-hyped tour, her career would take many twists and turns. Sissieretta Jones eventually performed in venues like Carnegie Hall and Madison Square Garden. She was the highest-paid Black female performer of the nineteenth century and a role model for future generations of Black performers.
This document is protected by copyright law. Use of the services of Érudit (including reproduction) is subject to its terms and conditions, which can be viewed online.

https://apropos.erudit.org/en/users/policy-on-use/ 


\title{
HERMENEUTIC LOOPS
}

\section{On the Record: Sissieretta Jones and Black Feminist Recording Praxes}

\author{
Kristin Moriah
}

After the spotlights faded, few reporters bothered to note the details of her daily life. So, while Sissieretta Jones might have once been billed America's first Black superstar (among other superlatives), information about her final years is sparse. We know that she retired to Providence, Rhode Island. She sold various rental properties and sundries once the money started running dry. She may or may not have worked as a housekeeper for a wealthy white family in town (Lee 237). And despite her reduced status, eager eyes scrutinized her while she tended her rose garden. Her shadow loomed large for the children in her neighbourhood. Years after her death, those children would reminisce about the theatre impresarios, Black actors, and celebrities who passed in and out of her door (McGetrick 1980). The details of her last days, the contents of her parlour, and the state of the home in which she spent her final days took on a mythological status in their memories and local lore. As such, one of the significant interventions made by Dr. Carl R. Gross, "the primary physician to the black community in Providence for several decades" (Carl R. Gross Collection), and a former neighbour of singer Sissieretta Jones, was providing a detailed depiction of the domestic life of the performer at the end of her career. Describing Sissieretta Jones's home in Rhode Island, Gross painted a picture of opulence:
Madame Jones spent a quiet life with some of the treasures collected in her former days: a large oil painting of the Grand Canal by C. Valette, a Corot, a Murat, and the "Old Mill" by C. Ruette, all famous artists. The top of her walnut piano was covered with autographed pictures of many artists, notably, Madame Melba, ${ }^{1}$ Cole and Johnson with their famous song, "Mudder Knows" and many other pieces of sheet music. Also retained were her two fur coats, her wardrobe of some of the wonderful evening gowns loaded with sequins, some gorgeous airgrets [sic], gloves: and other finery, the three gold medals, her scrapbook, photographs of herself and her parrot which she bought 28 years ago in Argentina. (Gross 1966, 5)

So much can be made of the tableaux. The European paintings illustrate the singer's interest in fine art and her keen aesthetic sensibilities. The juxtaposed photographs of Australian opera singer Nellie Melba and Cole and Johnson speak to the reconciliation between art music and the variety stage that defined Sissieretta Jones's career. In the evocative list of coats, costumes, jewelry, and the no doubt colourful plumage of her exotic bird, it is easy to lose track of something as seemingly mundane as a scrapbook. But Sissieretta Jones's scrapbook is a complex document that provides rich material evidence of the singer's innovations in the field of sound and performance.

Today, Sissieretta Jones's scrapbook is held in the Moorland Spingarn archives at Howard University and remains an important source of information about the performer and her life. Hovering at the margins of both mainstream (read: white) nineteenth-century press coverage and contemporary database search tools, the voice that Jones wanted to be heard is tangible in her scrapbook. Ellen Gruber Garvey (2013) might argue that the scrapbook was "published" once it entered into

Kristin Moriah is assistant professor of English at Queen's University. Her research interests include sound studies and Black feminist performance, particularly the circulation of African American performance and its influence on the formation of national identity. 
Howard's archives. It was donated to the archives by Carl R. Gross, who explained that he was given "the three medals, scrapbook, photographs, etc.," by "Mr. William P.H. Freeman, a Negro realtor and past president of the local N.A.A.C.P" who, "knowing I was interested in Negro history in Rhode Island, said, when my eyes are closed, these things might be thrown out and lost to posterity" (Gross 1966, 5). The scrapbook is a repurposed Bank of Nova Scotia Canada ledger. Was the choice of material a tacit critique of the commodification of Blackness on the variety circuit? Or was it simply a matter of making the most of what was at hand when she was on the road? We may never know the answers to those questions. But the scrapbook documents Jones's career from 1892 to 1899. It contains over three hundred articles, cut and pasted, often overlapping, which discuss Jones's performances and career. Many of the articles in the scrapbook lack distinct publication information like the titles of the papers from which they were culled. The effect of handling the fragile tome and reading about Jones therein might be disorienting if not for the unending emphasis on the singer's voice. Indeed, in Gross's biographical sketch, despite only having heard Jones sing once (5), he notes that he relied on evidence from her scrapbook to make claims about the nature of her voice throughout her career (1) and includes an appendix of "some quotes from her personal scrapbook about her voice" (6). Gross's fascination with the singer's voice suggests his own curiosity, longing, and sense of loss-feelings that have become a motif for her biographers.

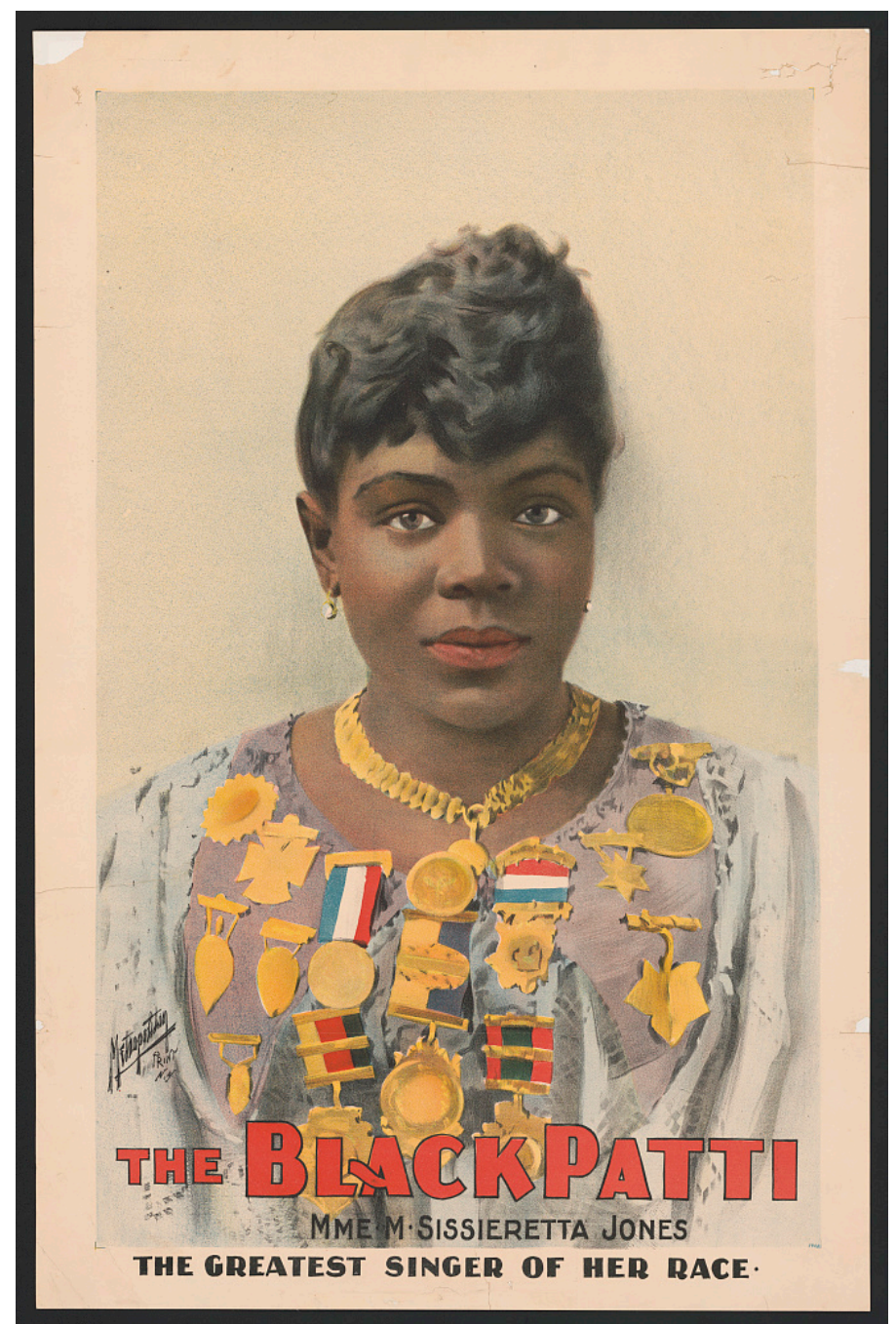

Metropolitan Printing Co. The Black Patti, Mme. M. Sissieretta Jones the greatest singer of her race. 1899. Photograph. 
Attention to the scrapbook reveals how Sissieretta Jones ${ }^{2}$ strategically leveraged her European performance reviews to increase her listenership and wages in the United States. Jones toured Europe for the first (and only) time from February until November in 1895. According to clippings that she provided to African American newspapers, the singer performed at the renowned Winter Garden in Berlin for three months. Jones also claimed that she performed for Wilhelm II, the last German Emperor and King of Prussia, at his palace and was subsequently presented with an elaborate diamond brooch for her performance. Afterward, the classically trained opera singer told the African American newspaper the Indianapolis Freeman that she would like to live in Europe permanently. Her biographers frequently cite the success of this trip and its symbolic importance for African Americans. ${ }^{3}$ And yet, evidence of these events in the archives of major German newspapers is elusive and contradictory at best, if it exists at all. Nevertheless, after the much-hyped tour, her career would take many twists and turns. Sissieretta Jones became a prototypical turn-of-the-century Race Woman: ${ }^{4}$ a classically trained opera soloist who sang in venues like Carnegie Hall and Madison Square Garden. She was the highest-paid Black female performer of the nineteenth century, and she was a role model and dynamic mentor for future generations of Black performers.

Archival records reveal how sound was central to Jones's understanding of herself as a spokeswoman, quite literally a formal voice for her race in the 1890s. Here, it is important to note that although she performed at the dawn of the recording age, early Black art musicians were rarely recorded. These conditions have resulted in a paucity of audio records of early Black performance. No known audio recordings of Sissieretta Jones's voice exist. But as she laboured in performance, Jones embodied Blackness, reproduced that Blackness for her listeners, and actively recorded it through textual means. This process of recording her sound at a moment in which records of Black lives and deaths were a matter of utmost urgency reflects the political necessity of recording her voice in its true texture and context. What might it mean to "listen" to Jones through the texts that she constructed, limited though they may be? I argue that imbrications of text and sound foster productive readings of Jones's work, and we must approach her life with an ear for sound even as we read. Jones's transnational work reveals the multifold complexities surrounding nineteenthcentury African American women's performances and the sound of their voices.

In the course of this investigation, I treat Black women's voices as social objects or concrete rallying points within the African American community and suggest that Black artists shaped the quality of that object for personal and political gains. Sissieretta Jones's performance reviews and interviews, especially those she personally disseminated and collected in her scrapbook, reveal particular attention to the voice as just such an object. My research demonstrates that the transmission and transcription of sound were profoundly important to women like Jones, who often went to great lengths to control their sound and manage their quality. Black women used subversive recording and listening practices to subvert the structural racism that subtended their American performances. While I hope to avoid dwelling too long on what might be considered simple wordplay, I believe that viewing Sissieretta Jones's textual reproductions of her voice as analogous to producing and keeping a race record can help us further understand the nuances of Black performance at the dawn of the twentieth century. In this work, I also consider African American performance in Germany as a complex site for the production of music and acoustical innovation. In simple terms, Germany does something different for Black singers, musicians, and performers. Matthew Morrison points out that the "anti-Black ideologies that shaped both European and American society in the late nineteenth century as musicological discourses took shape" can be traced to musicology's German roots (2019, 782). Identifying Germany as a significant location for African American classical musicians between World War I and World War II, Kira Thurman has argued that "musical 
performances occasionally rendered the categories of Blackness and Germanness, long presented as separate in transatlantic discourse, malleable or fluid" and that musical experiences were processed "through a racial filter" (2019, 831). Given these conditions, despite her reputation as a genteel, if not meek, Race Woman, the way Jones deployed her German performance reviews reveals the transgressive social and political uses of sonic records in transnational contexts.

This work extends notable recent contributions to the field of Sound Studies which take the relationship between sound and race as their main focus. I am particularly indebted to Jennifer Lynn Stoever's The Sonic Color Line, in which she insists that sound is "a critical modality through which subjects (re)produce, apprehend, and resist imposed racial identities and structures of racist violence" $(2016,4)$ and reveals "the dynamic relationships between racial ideologies, the development of sound media, and the modern listening practices that shape (and are shaped by) them" (4). Following Stoever, who argues that "sound functions as a set of social relations and a compelling medium for racial discourse" (2016, 7), I argue that Black female performers were acutely aware of the political nature of sound and voice. Nina Sun Eidsheim has termed that particular conflation of race and sound acousmatic blackness and defines it as "the perceived presence of the black body in a vocal timbre" (7). Echoes of Alex W. Black's term resonant body can be found here, too. Taking mid-nineteenth-century performers Elizabeth Taylor Greenfield and Mary Webb as his focus, Black's concept “emphasizes the influence a performer's voice had over the way a reviewer saw her body. It also suggests how her voice resounds in descriptions of her body. For these women, to become textualized was not to become abstracted" (2011, 620). Black posits that for women like Greenfield and Webb, "embodiment was realized in print. The voices of these performers call attention to their corporeality. These calls are answered by representations of their bodies that show the traces of their vocalization. The sight and sound of the body in performance, in other words, is remediated as text" (620). Even though she performed during a later period, this is no less true for Sissieretta Jones.

\section{Writing Sound with Scissors}

My research begins in the 1890s, also known as the Red Decade, a period in which lynching and racial violence rocked the nation on a nonstop basis. Years of post-Emancipation progress were erased as the United States government retracted many of the hard-earned rights of Black Americans, calling their very citizenship into question. At the same time, as Gustavus Stadler (2010) has shown, the 1890s were a decade in which lynching recordings interspersed with coon songs became popular commodities. Such "recordings were very much in the mainstream of the emergence of the recording industry as a major form of commercial entertainment" (Stadler 2010, 95), eventually helping to "modernize and further capitalize a longstanding fascination among whites with black voices, as well as fantasies about the relationship of black voices to black bodies" (96) that is rooted in racial terror and violence.

The 1890s also saw an increase in the international popularity of Black music. An influx of African American vaudeville performers arrived on European shores. For African American performers, travelling abroad was often a matter of survival, providing an opportunity to work and live in less hostile environments. Several African American variety acts established robust careers in Europe while remaining virtually unknown in the United States and relatively neglected by the Black press. ${ }^{5}$ For others, success in Europe formed a repudiation of American racism. Race, recording, and performance were deeply intertwined in this period. Although Germany was the centre of the music 
publishing world and sound recording in the late nineteenth century, no recordings of Sissieretta Jones's performances there, or in the United States, have been preserved. ${ }^{6}$ The closest that we can get to listening to the singer involves working through the archives to discover accounts of her stage performances by reviewers and in-person interviews by Jones. During her lifetime, written reviews made her performances almost equally accessible to Black and white audiences around the world. Newspaper readers could use these reviews to imagine and approximate her sound.

When we look at nineteenth-century scrapbooks and assemblages of newspaper clippings made by Black performers, we repeatedly see Black women who extracted self-representative text from hostile contexts to shore up their reputations in ways that are strikingly progressive and anachronistically modern. I liken scrapbooking by Black women performers to a deep and at times transgressive engagement with print technology. Through the mechanism of the scrapbook, the women I write about preserved and assembled textual versions of themselves which offered readers alternate views of their lives and works outside of the circumscribed world of mainstream print media. In this area of research, I am preceded by Ellen Gruber Garvey, who has argued that "scrapbook work and the understandings of information that it developed allowed people to see newspapers as extractable data. They mark the path from scrapbooks to our current age of digital information" $(2013,229)$. Like Garvey, I see value in understanding the ways older relationships to print media continue to impact our current information management and interpretive practices. And so, I argue that the printed word represented a vital technology for new forms of self-articulation that also bleeds into fields like Sound Studies. In other words, through their scrapbooks and clippings, Black women actively reshaped the way their sound would be perceived "live" and in the past tense. Shaping their sonic reception through print culture, they navigated the hostile terrain of early sound technology and media.

Scrapbooking, or what Garvey has termed "writing with scissors," was a critical sound recording method for Black women vocalists in the nineteenth century. Garvey argues that "scrapbook makers' work mirrored the practices of newspaper editors" $(2013,5)$ and reminds us that "actors were particularly avid scrapbook makers. The reviews and playbills they saved supplied evidence that long-vanished performances had taken place, and they sometimes used their books as a job-hunting aid to show to theater managers" (10). Garvey's claims certainly ring true for performers like Sissieretta Jones, an avid scrapbooker. Furthermore, she notes that

African Americans and feminists are among those who have sought to create archives that include their history and experience ... they seek not only to have their material enter into existing archives, but to preserve their own systems for ordering knowledge, and to assert their own systems for controlling access. (Garvey 2013, 209)

Garvey's claims are illuminating when taken into consideration alongside sound theorist Mladen Dolar's conjecture that "the written word has no power if it is not preceded by, and based in, the living voice. The authority of writing depends on its being the faithful copy of the voice" (2006, 109). Collecting, curating, and arranging evidence of her vocal performances placed Sissieretta Jones in the role of editor and sound innovator. Within this framework, Jones's personal scrapbook and public sound curation becomes crucial evidence of her "object voice" and her ability to record, control, and deploy her own sound in public discourse. 
Searching for the presence of Jones's voice in the archive, I also seek evidence of her humanity beyond the role of exceptional Race Woman. One of the problems with fleshing out a more threedimensional version of Jones is that while much was written about her, little was written by her. A further layer of complexity is added when we consider that her "official" nickname "Black Patti" was later adopted by a successful record label, one whose outputs Jones distanced herself from. More recently, the name Black Patti has also been adopted by a white German duo who perform acoustic blues of the kind produced by the 1920s record label. Thus, if we are to discover Jones's voice in the archives, we must do so through an unorthodox approach to written text, an artifact that is itself an attempt to visualize her sound. In the absence of any personal written records, archival records, including her scrapbook and its selections, reveal how sound was central to Sissieretta Jones's understanding of herself and her role as a spokeswoman, and formal voice, for her race in a transnational context. The voice that she wanted to be heard remains present in these records.

And yet, Sissieretta Jones's interviews and newspaper reviews are important sonic records and evidence of the way she conceptualized sound. As she laboured in performance, Jones embodied Blackness, reproduced that Blackness for her listeners, and actively recorded it through textual means. This jerry-rigged process of recording her sound at a moment in which records of Black lives and deaths were a matter of utmost urgency reflects the political necessity of recording her voice in its true texture and context. Here, my case rests on the multiple implications of the recorded word and sound in African American print culture. Perhaps, to some extent, all writing is meant to reflect sound or the spoken word, but our understanding and expectations have changed. The process of writing the voice with scissors, or textual sound recording, becomes even more complicated when we consider the intimate relationship between sound, text, and body. Voice and text compete for meaning, although they are not easily separated. As such, as Alexander Weheliye notes, "the voice, even more so than writing, represents the pure interiority and the proper domain of the sovereign human subject" $(2005,27)$. However, until relatively recently, it was only as a written language, or a record, that the voice could be archived or transcend time and space. The sovereignty represented by the voice was fragile and always temporal for marginalized subjects. The practice of reclaiming that voice through the organizing of text and printed matter pushes back against societal structures that seek to deny Black sovereignty.

Black women who performed art music were formally excluded from early phonographic recordings, but they and their work continued to exist in relation to it. We can apprehend Sissieretta Jones's relationship to textual records of her voice through sound technology, particularly phonography. Lifelong comparisons between Jones and Italian opera singer Adelina Patti marked a through-line between Jones's work and the careers of other Black singers whose nicknames helped readers approximate their sound by way of racial binaries, as with women like Elizabeth Greenfield (aka the Black Swan). Opportunities to hear Sissieretta Jones in concert might have been limited, but one might get a sense of Jones's voice by way of favourable and accurate reviews and recordings of Adelina Patti's voice. She collected and archived such reviews regularly. As Nina Sun Eidsheim shows, the timbre of the Black voice was a concern to both listeners and performers. So, too, was an attention to the ways this racialized sound was recorded and circulated, often in the absence of the audio record. An awareness of the phonograph's early existence as a dictation device further emphasizes the complex relationship between sound and writing. Writing sound with scissors, or curating one's press clippings, provided a means for closing such hermeneutic gaps. 
I seek to expand our understanding of the powers of alternate forms of sound recording as a means of restoring the humanity of minoritized performers who have been excluded from audio archives. Read quite literally, records of Black voices and Black presence in their artistic and cultural dimensions are political acts. We must remain cognizant of the fact that for African Americans, the act of testifying, and of recording that testimony, is especially significant. Here, I briefly turn towards Ida B. Wells's Red Record (Wells-Barnett 1895) to consider how the act of Black recording was an imperative for Wells, the ways those records exist within different mediums, and the ways Black voices were systematically expunged from the public record. Speaking of the political nature of recording, Wells writes: "It becomes a painful duty of the Negro to reproduce a record which shows that a large portion of the American people avow anarchy, condone murder and defy the contempt of civilization." The racial record that Wells refers to takes numerous forms, including bodily inscription. Highlighting the complex intersection of sex and gender in the recording of these race records, Wells also notes that:

True chivalry respects all womanhood, and no one who reads the record, as it is written in the faces of the million mulattoes in the South, will for a minute conceive that the southern white man had a very chivalrous regard for the honor due to the women of his own race or respect for the womanhood which circumstances placed in his power. (WellsBarnett 1895, 14, emphasis added)

Wells's work highlights Black women's unique role in the spectrum of racial violence that rocked America. It also underscores the plasticity of the public record and how the very act of recording is made visible through the Black body.

\section{"Die Wirkliche Black Patti" and the Colour of Sound}

I read the press clippings about Berlin that Jones provided to the Indianapolis Freeman in the article "Mme. Sissieretta Jones" against a range of primary sources and ephemera, including the sources that Jones chose to omit. We know for a fact that Sisseretta Jones began her European tour in Berlin in 1895. Afterward, she publicly insisted upon her success in Europe and expressed a desire to stay there for an extended period at a future date. The European tour signified a triumph for Jones, the African American community, and the Black diaspora. But my archival research reveals that such claims might not have been entirely accurate. As primary sources compiled by Rainer E. Lotz show, Jones was preceded by a "fake" Black Patti (Lotz 1997, 29). ${ }^{7}$ That "Black Patti" was a flop on Berlin's stages, and the negative reception might have tainted Jones's audiences. And yet, Sissieretta Jones's African American readers interpreted her acceptance by German audiences as a true measure of her talent in ways that reviews by white Americans did not. But questions of race and authenticity haunted the performer. In her German reviews, an insistence on her lightness, or a denial of her darkness, seems analogous with praising her musical talent. German reviewers simply could not say that Jones was a good singer while calling her "black." Thus, a reviewer from the Borsen-Courrier wrote the following:

Our trans-atlantic cousins have not exaggerated comparing their country-woman with Patti, but the adjective "black" seems to us unnecessarily impolite. Miss Jones is evidently of Negro blood, but not alone of Negro blood. She is a mulatto of bronzed complexion and pleasant expressive features, with full lips and high forehead and the bearing of a lady, even to the choice of her costume. 
But was Jones an authentic representative of African American culture? Or did she merely ventriloquize whiteness? How was her humanity made manifest in performance? Kira Thurman's (2019) assessment of Black performance in interwar Germany resonates here, too. She suggests that "the audience's practice of racial listening thus reflected transatlantic conversations on blackness and proved that Western art music and its oft-touted, supposedly benign message of universality could not escape the politics of race and nation; rather, it had become complicit in them" (Thurman 2019, 834).

In the Borsen-Courrier review, Jones's physical description calls the reader's attention. For a readership steeped in nineteenth-century racial theory, Jones's mouth signified "a rather dull gross nature, and of some indolence in the disposition" à la European phrenologists like George Burgess. And yet, astoundingly to some, she was a more than a competent singer. Seeking out degrees of racial purity in Jones, her reviewers supported racial theories by eugenicists like Eugen Fischer, who believed that people of African and European descent "were fairly intelligent" and even "superior to full-blooded black Africans," but still "far inferior to Europeans in their creative abilities" (Weikart 121). People of African descent were unable to labour or create without the guidance of whites. They were machinic and yet childish in their orientation to the world. In the schema Louis Chude-Sokei (2015) outlines, they are reminiscent of automata. On a larger scale, such theories were used to justify forced African labour within the German colonies. In the German concert hall, being Black meant that, for her reviewers, Jones could not produce authentic sounds of her own but merely parrot the sounds of more authentic and talented women of European descent like Adelina Patti. Kira Thurman explains that these characteristics of Black reception in Berlin lasted well past the nineteenth century:

Audiences routinely resurrected racial barriers in response to black performers' musical attempts (intentional or otherwise) to dismantle them. White listeners' struggles to come to terms with black musicians' performances are proof that musical reception was not a passive experience but rather an active process whereby racial categories were being worked out and renegotiated in interwar central Europe. $(2019,831)$

Despite her publicity efforts, Jones was unable to filter out reviews that revealed German fixations on colour. For example, from the oft-cited reviews published in the Indianapolis Freeman, likely furnished by Jones and her management, we see that readers of the Kreur-Zeitung were assured that Jones was the "true Black Patti," that "singer of repute in America," but also that she was "a mulatto of pleasing appearance." German reviewers were hard-pressed to overlook the contradictions between what they were hearing and seeing when it came to Sissieretta Jones. Still, Jones subverted racist ideas throughout her performances. Having the bearing of a lady, in costume and comportment, differentiated Jones from the depictions of labouring Black women that were popular on stage and in the surrounding culture. It certainly distinguished her from figures found in piccaninny shows and human zoos, and nothing could have been further from the traditional portrayal of Black womanhood on the popular stage. In her costume and choice of staging, Jones resisted the ethnographic tendencies that characterized typical portrayals of Black womanhood in the United States and on the international Vaudeville and Varieté circuits. There are explicit connections between her sartorial choices and the other forms of textual/tactile editing Jones practised. 


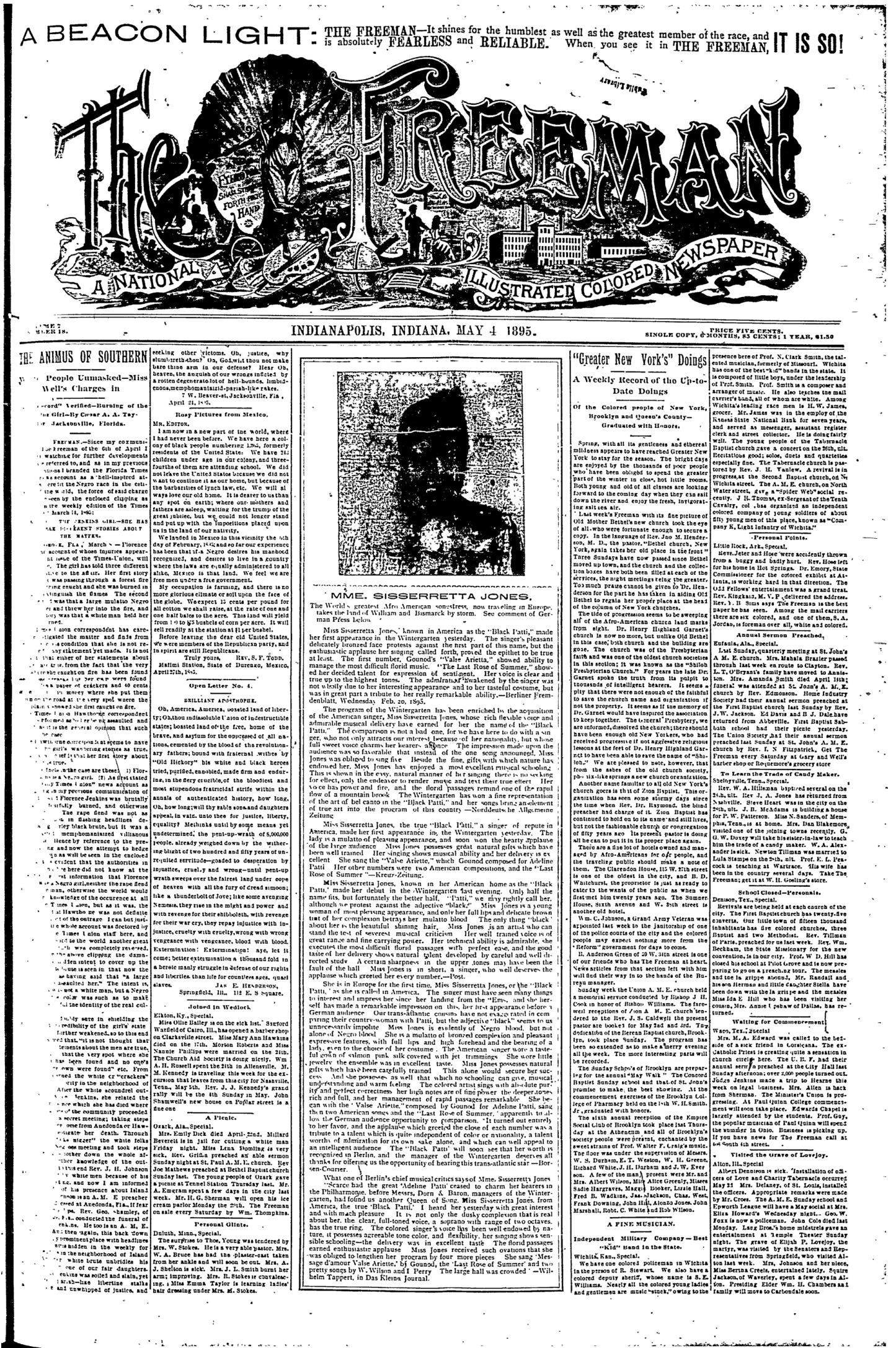

Front page of the Indianapolis Freeman, May 4, 1895. Schomburg Center for Research in Black Culture, Manuscripts, Archives and Rare Books Division, The New York Public Library. 
But what are we to make of the fact that Jones provided these racist clippings to the Indianapolis Freeman? What sorts of nuanced differences between American and European listenership did they represent to Jones and her African American readers? Jones's description of her German reception signifies stereotypes about German affinities for music and acoustical knowledge and may have functioned as a coded challenge to white American listeners while vindicating African Americans. As such, Sissieretta Jones leveraged Eurocentricism and racial capitalism against American racists on their own turf. Jones's German reviews contradict the ways she framed Europe in the press. In an interview in the Toronto newspaper the Empire, later to become the famed Globe and Mail, Jones claimed that

in Europe there is no prejudice against my race. It matters not to them what is the color of an artist's skin. If a man or woman is a greater actor, or a greater musician, or a greater singer, they will extend a warm welcome, no matter whether he be Jew or Greek or Gentile. It is the soul they see, not the color of his skin. (n.d.)

This commentary signifies the interrelated nature of place and sound. Her reviews suggest that foreign spaces contained white audiences who could hear her in ways that were impossible on US soil. When she performed in Berlin, many German reviewers refused to register visual evidence of Sissieretta Jones's phenotypical Blackness even though she was born to two African American parents. All visual materials and photographs of Jones produced during her lifetime depict her as a dark-skinned woman who would have trouble passing for anything other than African American in the United States. Sissieretta Jones's voice produced discordant visual effects, troubling developing German rubrics about Black humanity through performance.

Statements like those found in the Empire appear to have been taken at face value by her readers and critics. They matched standard tropes about travelling in Europe while Black during the late nineteenth century. Jones saved a clipping of the interview in her scrapbook. But given Germany's increasing investment in racial hierarchies in continental Europe and Germany's African colonies at the time, her statements are striking. I wonder, from Jones's perspective, what made Germans better equipped than white Americans to see beyond the skin and into the soul? How can we understand the difference that race makes to transnational listeners during the late nineteenth century? How is it possible that the differences in what Germans heard and saw could be used to Jones's advantage? There is a discrepant reading practice at play among the African American reading public. One of the things we witness in Jones's descriptions of her German reviews is an early example of a kind of colourblind ideology that Jones used to bolster her personal project of racial uplift. Sissieretta Jones's insertion of these German reviews into African American newspapers, akin to scrapbooking on a public level, shifts the conversation from a context in which race itself was blinding and threatened to blot out other senses, especially the audial, and quite literally prevented her from being heard by segments of the American public. Jones's German reviews suggest that in Berlin, a place where race was unseen, or at least improperly interpreted, she could truly be appreciated by white listeners. Here, we also see evidence of the German practice of "blind listening," literally looking away from a performer, which Jennifer Stoever delineates in the Sonic Color Line (2016, 115). Thus, readers also learn that Jones's voice had the power to blur the colour line. Jonathan Wipplinger suggests that such moments "of misrecognition" carry with them "profound implications in terms of the role of race in the opera's reception" in Germany (Wipplinger 2012, 247).

The focus in Jones's reviews on what German audience members could or could not see and hear also speaks directly to the problem of racial uplift that Black classical musicians sought to address. 
African American women who performed classical music in the public sphere had to prove that they had talent despite their appearance and that finely trained voices and Black bodies could be intertwined. It is precisely that which was denied to them in the mainstream American press. Jones's performance of racial uplift certainly made her appear less "black" in the eyes of German audiences. As such, the transnational performances of art music by Black divas that were so central to the project of racial uplift disrupted precisely that which they sought to represent-a more expansive understanding of Black life, art, creativity, and talent. Sissieretta Jones's experiences performing classical musical abroad reinforce opera scholar Naomi André's assertion that

opera has proved to be a flexible and capacious genre. It can give voice to the experiences that exist outside the mainstream; with the participation of black composers and librettists behind the scenes, black bodies and embodied stories on the stage, and black audience members interpreting the performance, opera compellingly expresses multiple vantage points that have not previously been staged. $(2018,14)$

Beneath the Berlin Wintergarten's glittering glass ceiling, Sissieretta Jones sang popular American songs in addition to classical music that was part of her typical repertoire. Some of those popular songs were part of Adelina Patti's repertoire, openly inviting comparisons between herself and the Italian diva. Adelina Patti performed those numbers in Berlin with the Philharmonie only a few weeks before Sissieretta Jones made her debut there. In the reviews Jones circulated, we glimpse how she not only mimicked Adelina Patti but made Adelina's repertoire sonically Black. As I have suggested, being in Berlin prompted Jones to experiment with sound and recording praxes in new ways. In contemporary terms, we might think of Jones's treatment of Patti's set as a remix. Popular songs the two divas shared included "Maggie, the Cows are in the Clover," "Comin' Thro' The Rye," "Last Rose of Summer," and "Home Sweet Home" (Daughtry 1968, 199). We know that at the very least, from this shared list, Jones performed "Last Rose of Summer" for her Berlin audiences. In their depiction of a simple, pastoral life, the songs in the divas' shared repertoire are markedly different from the Negro Spirituals that German audiences would have become accustomed to in concert settings that featured Black performers, as with the Fisk Jubilee Singers. These popular songs and ballads are the inverse of Negro Spirituals in their depiction of an uncomplicated and unforced relationship to the land, rural life, and labour. Performing these songs, Jones actively resisted staged representations of Black labour in favour of Black leisure and pastoral innocence.

These popular songs are also free of the overtly religious overtones that characterize the Negro Spiritual tradition. One of the few articles attributed to Sissieretta Jones was entirely about the importance of Negro Spirituals, which suggests that their omission from her repertoire was highly significant. Notably absent from Jones's reviews are any mention of her performance of Stephen Foster's minstrel song "Swanee River," which she regularly sang for American audiences. What's more, popular ragtime coon songs were not part of Jones's repertoire, and that was probably a disappointment for German listeners, too. That is also a glaring omission, given that, even more than the Negro Spiritual, which fuelled the wild success of choral groups like the Fisk Jubilee Singers, ragtime coon songs had begun to be recognized across the globe as the most authentic genre of American music (Abbott and Seroff 2003, 3) by the 1890s.

Jones's on-stage refusal of racial stereotypes surrounding Black womanhood distanced her from "Blackness" when it came to white European listeners. To be sure, Kira Thurman notes that "one- 
way critics distanced singers of art music such as Sissieretta Jones from popular Black entertainers was by describing these musicians as much lighter in appearance than their African counterparts in Völkerschauen and circuses" $(2013,67)$. Through Jones's German performance reviews, we see how for white European audiences, African American women's performances of classical music in Germany threatened to destabilize the connection between race and performance. Unlike Sissieretta Jones, Black women typically appeared on European stages in roles that reinforced notions of white supremacy and justified colonial impulses. One way the discrepancies that performances by women like Sissieretta Jones could be reconciled by white European viewers was to deny the presence of their Blackness or to mute it.

Jones also pushed the boundaries of Black performance and sound through her choice of vocal technique. In Berlin, Jones was praised for her use of bel canto. Writing about her own work reconstructing Samuel Coleridge Taylor's Setting of Paul L. Dunbar's “A Corn Song," researcher Tsitsi Jaji (2013) explains how certain styles of vocal inflection can call forth Black diasporic meaning. Of her project, Jaji writes that

my decision to sing the entire song in bel canto style (and primarily in head rather than chest register) prioritizes Coleridge-Taylor's Afro-British interpretive reading and this emphasizes the gap of the Black Atlantic, whereas if I had chosen to employ such US black vocal techniques as tone bending, greater chest resonance, and a triplet-based rhythmic feel in the section representing slaves in song, the poem's internal tensions might sound more starkly. $(2013,202)$

In keeping with Jaji's contemporary description of her artistic choices in her performance of Black diasporic art music from the nineteenth century, I suggest that what we are witnessing in descriptions of Sissieretta Jones's voice from her Berlin engagement is Jones's attempt to demonstrate the ways race influenced her musical style. For instance, a reporter for the BorsenCourrier wrote that Jones possessed "that which no schooling can give, musical understanding and warm feeling." Could the natural musical affinity the writer describes express more than just his understanding of Black music? W as it the performance of a Black musical style? Colour and vocal range are so closely intertwined in these reviews it is hard to imagine otherwise. For example, Wilhelm Tappert of Das Kleine Journal explained:

It is not only the dusky complexion that is real about her, the clear full-toned voice, a soprano with a range of two octaves, has the true ring. The colored singer's voice has been well-endowed by nature, it possesses agreeable tone, color, and flexibility.

One must note the repeated insistence that in Jones's voice, there was a tonality that goes beyond that which is human and sensate, or which could be educated. In their insistence that Jones was unconscious of the effects of her voice and artistic choices, analogies can be made between Jones's vocal presentation and the work of the phonograph. For example, Norddeutsche Allgemeine Zeitung readers learned that

in the easy, natural manner of her singing[,] there is no seeking for effect, only the endeavor to render music and text their true effect. Her voice has power and fire, and the florid passages remind one of the rapid flow of a mountain brook. (emphasis added) 
For Jones to seek effect, or to seem to seek effect, would be for her to break yet another illusion accompanying the performance of race on the German stage. In denying Sissieretta Jones's artistic agency and reducing her performance to an almost ethnographic demonstration of innate musical talent, these reviewers aligned Jones's performance with a history of unthinking Black labour represented by foremothers on the popular stage like Joyce Heth. And yet, there is strong evidence to support the idea that Jones was aware of the social nuances surrounding the Black voice. She harnessed the power of these nuances to powerful effect long after the curtains had closed.

\section{Conclusion}

I have argued here that Sissieretta Jones's use of German performance reviews reveals strong articulations of her voice and demonstrates how Jones positions herself as a global subject whose textual self-construction was resistant to American racism. In her personal scrapbook, in particular, Jones took special care to collect reviews that mention her voice. The reviews she kept do not prevaricate on the nature of her vocal talent. An addendum to the scrapbook, written after her death, also in the Howard archives, is entitled, "Some Quotes from Her Personal Scrap Book about Her Voice" and contains the following: "if Madame Jones is not the equal of Patti, she at least can come nearer than anything the American public has heard. ... Her notes are as clear as a mocking bird and her enunciation, perfect" (7). Quotes like these emphasize the importance of her achievement on an international level for Jones and the African American community writ large.

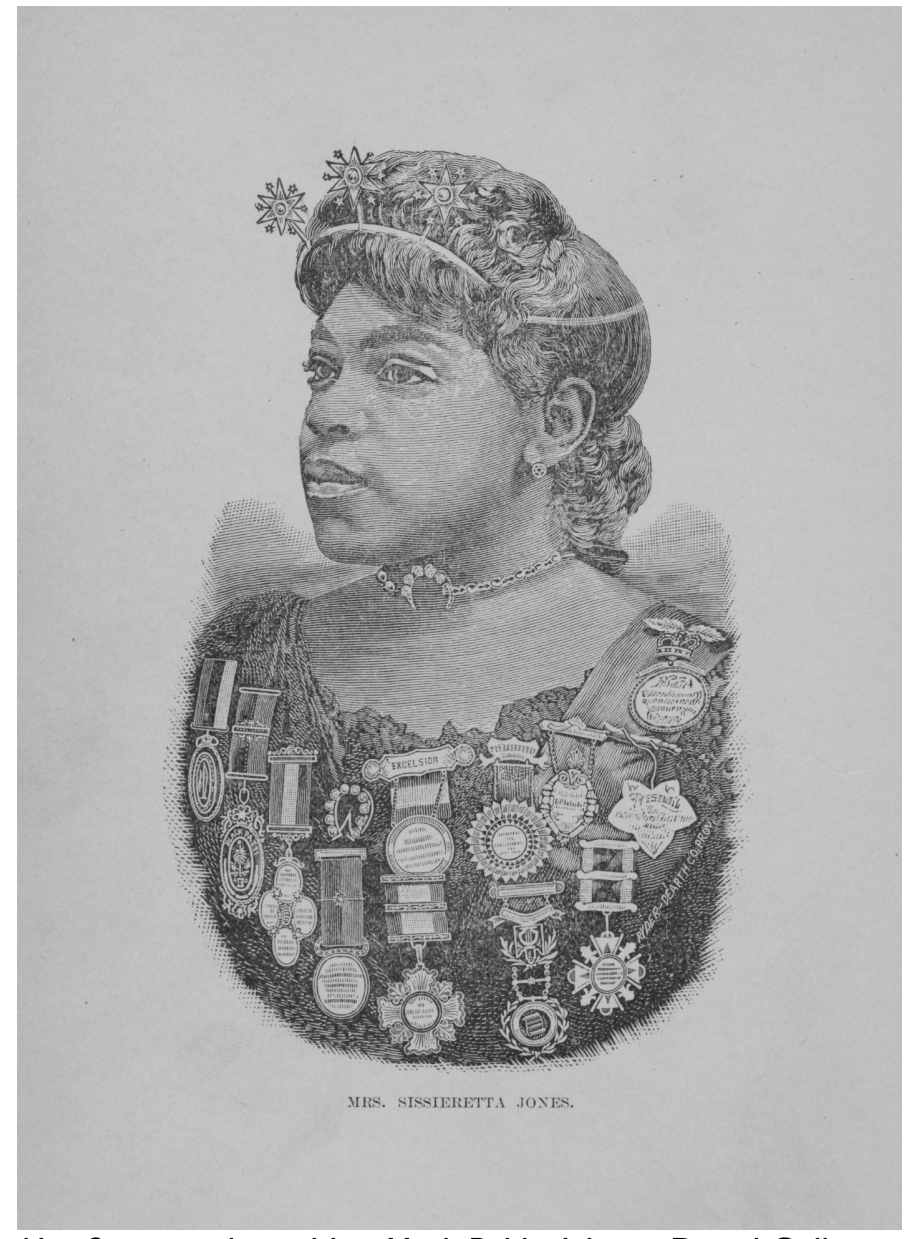

Mrs. Sissieretta Jones. New York Public Library Digital Collections. 
My analysis relies on an interdisciplinary approach to textual evidence of sound and an understanding of the complexities of these reviews within their historical context. The multidimensional nature of sound and its ability to be read across genres, mediums, and spaces is critical here. In Berlin, Germany, and the rest of Europe, Black women made sound visible through image and text, contributing to the narratives of black culture and diaspora. Despite being on the margins of mainstream audio recording, Black women performers used the foreign stage to perfect their sound and make it a legible aspect of their stagecraft. In doing so, they produced new ways of interpreting the world and bending it to their will.

But what did Jones have to say about her work and travels? An article from the Louisville Commercial entitled "Not Pleased: The Black Patti Thinks Her People Not Well Treated" contains a rare interview with the star. Jones expressed displeasure about the segregation of her audiences into white and coloured seats even though there were plenty of vacant seats in the white section, saying quite simply "I think people of my race ought not to be shut out" in that way. Jones also complained about the difficulty she and her accompanist, Mrs. Alberta Wilson, also African American, had finding lodging in Cincinnati: "We had so much trouble at the hotels in Cincinnati. ... We had to search and search before we ... could find a nice place." "Not Pleased" ends with a gloss on Jones's plan to pursue music studies in England, "where people of her race are not only received but when attractive by reason of endowment or acquirement in art, letters or science courted." Whether or not this was the case, by writing with scissors on the pages of her scrapbook and in the Black press, Jones created conditions under which this affirmation could be understood to be true. The seeds that she planted impacted Black performance for generations. After failing to find mainstream acceptance and performance opportunities as a singer of art music after her Berlin tour, Jones headed a successful black variety troupe, the Black Patti Troubadors. The Black Patti Troubadors was an incubator for early twentieth-century Black performance: its rotating cast members would eventually include innovative Black performers like Aida Overton Walker, George Walker, Bert Williams, and Ida Forsyne (Lee 2013, 117). In their 1967 study of Black performance, Black Magic, Langston Hughes and Milton Meltzer claimed that her 1892 performance at Madison Square Gardens was one of "thirty-six milestones in the history of the 'Negro's participation in American entertainment”' (336). High praise indeed. But as Carl Van Vechten observed in his notorious 1926 Harlem Renaissance novel, her fame faded with the rise in interest in more popular forms of Black music.

More recently, Jones has inspired Pulitzer Prize-winning poet Tyehimba Jess, whose prose poem "Sissieretta Jones: ad libitum" (2016) treats the artist's complicated relationship with Europe, Black performance, and the Black diaspora. Speaking in the first person with a postmodern candour, Sissieretta Jones reveals the inherently political nature of Black performance work: while singing "with one hand smoldering in the steely canon" (Jess 2016, 162), her chorus "swells like a lynched tongue" (162) even as "the nocturnes boiling beneath the roof of [her] mouth extinguish each burning cross" (162). Here Jones's voice is not simply skilled or beautiful; it is a weapon that directly counteracts racial violence and turns its logic on its head. In Jess's poem, Jones knows the complex nature of her work and its ability to signify on issues as far-reaching as the Middle Passage. In a moment of synesthesia, we hear her "voice shimmering up from the Atlantic's hold" until she becomes "a coda of sail song whipped in the salted wind" (162). And how does she reach these heights? She chews Europe up and spits it out. In the opening line, the singer confesses: "I sing this body ad libitum, Europe scraped raw between my teeth until, presto, Ave Maria floats to the surface from a Tituba tributary of Swanee. Until I'm a legato darkling whole note ..." (162). Freely and with expression, she reconstructs the European elements of performance to create something distinctly 
Black and distinctly personal. Thus, in "Sissieretta Jones: ad libitum," Jones embodies and vocalizes the editorial techniques at play in her scrapbook and the Black press, remaking herself and her life experiences into a transcendent force that awes audiences and readers. It is the stuff of legends.

\section{Notes}

1. Born Helen Porter Mitchell in 1861, Nellie Melba was an Australian born soprano who enjoyed international fame up until the time of her death. The Cleveland Gazette claimed that during her 1894 visit to New York, Sissieretta Jones sang several selections for Melba, who "immediately told Mme. Jones that her voice was grand and also stated that Mme. Jones should go to Paris and finish under her instruction, and volunteered her services at the benefit for the same." Melba herself had trained in Paris; thus, the career advice that she gave to Jones was kind of advice that she had personally benefitted from. The Gazette also reported that Sissieretta intended to take Melba's advice and that "in a short time one of the greatest concerts ever given in New York will take place. The main artist will be Mme. Melba and the proceeds will be to finish the musical education of Mme. Sissieretta Jones in Paris." Unfortunately, according to Jones's biographer Maureen Lee, there is no evidence that this meeting between Nellie Melba and Sissieretta Jones ever took place or that Melba gave any benefit concert to pay for Jones to study abroad (Lee 84).

2. Sissieretta Jones was born in the bustling shipbuilding city of Portsmouth, Virginia, in January 1869. Her parents had emigrated there from North Carolina, another former slave state. Sissieretta began singing in local churches in Portsmouth at a young age. She began her formal musical training at the Providence, Rhode Island Academy of Music in 1883. Her formal entrance onto the popular stage took place in 1885 when she appeared at the Armory Hall, in Providence, with the legendary singer Flora Batson. In the United States, Jones embodied the potential for African Americans to master traditional European art forms and was celebrated in the African American press. After making her New York debut in 1888, Jones soon became an international sensation, touring the West Indies, South America, and Europe, in addition to the United States and Canada.

3. For example, Carl R. Gross wrote, "Morris Reno, president of the Carnegie Music Hall Association of New York, engaged her for a concert tour of the United States and Europe. She made her first appearance in Berlin, Germany, and the Berliner Zeitung said, "no sooner had the real Patti departed than a most worthy substitute appeared in the person of the Black Patti from America-The European engagement lasted eight months and no singer was ever received with more enthusiasm than Madame Jones. She received a royal command to appear before King Edward while in Britain and that popular monarch expressed the unqualified delight with her performance" (1966, 2).

4. According to Cooper, "any true race woman must be concerned not only with the moral and social character of the race, as the ideology of true womanhood dictated, but also with the intellectual character of the race" (2017, 13). For more on African American Race Women, see Carby (1987) and Cooper (2017).

\section{See Lotz (1997).}

6. This situation is not unique to Jones. Notable among the Library of Congress's "Lost Recording List" are a number of African American performers who performed in Germany to great acclaim, including the 4 Black Troubadors, Belle Davis and her Pickanninnies, the Darktown Entertainers, the Georgia Piccaninnies, H. M. (Henry Make) Johnson, Isabella Fields, Roland Hayes, and the Will Garland Negeroperette.

7. Citing the Berliner Zaitung [sic], a source Sissieretta Jones made a point of to sharing with the Indianapolis Freeman, "no sooner had the real Patti departed (Berlin) than a most worthy substitute appeared in the person of the Black Patti from America" (3). 


\section{References}

Abbott, Lynn, and Doug Seroff. 2003. Out of Sight: The Rise of African American Popular Music, 18891895. Jackson: University Press of Mississippi, 2003.

André, Naomi Adele. 2018. Black Opera: History, Power, Engagement. Champaign: University of Illinois Press.

André, Naomi, Karen M. Bryan, and Eric Saylor. 2012. "Representing Blackness on the Operatic Stage.” In Blackness in Opera, edited by Naomi André, Karen M. Bryan, and Eric Saylor, 1-10. Champaign: University of Illinois Press.

Aitken, Robbie John Macvicar, and Eve Rosenhaft. 2013. Black Germany: The Making and Unmaking of a Diaspora Community, 1884-1960. Cambridge: Cambridge University Press.

Baham, Angela Dean. 2011. The Unsung Diva. New York: New York International Fringe Festival. Black, Alex. 2011. "Abolitionism's Resonant Bodies: The Realization of African American Performance." American Quarterly 63, no. 3 (September): 619-39.

Carby, Hazel V. 1987. Reconstructing Womanhood: The Emergence of the Afro-American Woman Novelist. New York: Oxford University Press.

Chude-Sokei, Louis O. 2015. The Sound of Culture: Diaspora and Black Technopoetics. Middletown: Wesleyan University Press.

Cooper, Brittney C. 2017. Beyond Respectability: The Intellectual Thought of Race Women. Urbana: University of Illinois Press.

Daughtry, Willia. 1968. Sissieretta Jones: A Study of the Negro's Contribution to Nineteenth Century American Concert and Theatrical Life. ProQuest Dissertations.

Dolar, Mladen. 2006. A Voice and Nothing More. Cambridge, MA: MIT Press.

Eidsheim, Nina Sun. 2018. The Race of Sound: Listening, Timbre, and Vocality in African American Music. Durham: Duke University Press.

Garvey, Ellen Gruber. 2013. Writing with Scissors: American Scrapbooks from the Civil War to the Harlem Renaissance. New York: Oxford University Press.

Gross, Carl R. 1966. A Brief History on the Life of Matilda Sissieretta (Joyner) Jones, "The Black Patti" 18691933(?). Unpublished manuscript, Providence, Rhode Island, 1966.

Guerin, Frances. 2005. A Culture of Light: Cinema and Technology in 1920s Germany. Minneapolis: University of Minnesota.

Hughes, Langston, and Milton Meltzer. 1967. Black Magic: A Pictorial History of the Negro in American Entertainment. Englewood Cliffs: Prentice-Hall.

Jaji, Tsitsi. 2013. “Art Song Poetics: Performing Samuel Coleridge-Taylor's Setting of Paul L. Dunbar's "A Corn Song." J19: The Journal of Nineteenth-Century Americanists 1(1): 201-6.

Jones, Sissieretta. n.d. Scrapbook. Series B, Box 41, Carl R. Gross Collection. Moorland Spingarn Archives, Howard University, Washington, D.C.

Jess, Tyehimba. 2016. "Sissieretta Jones: ad libitum." In Olio. New York: Wave Books.

Lee, Maureen D. 2013. Sissieretta Jones: "The Greatest Singer of Her Race," 1868-1933. Columbia: University of South Carolina Press.

“Lost Recordings List.” Library of Congress. https://www.loc.gov/programs/ national-recordingpreservation-board/about-this-program/donations/lost-recording-list/ (accessed January 31, 2020).

Lotz, Rainer E. 1997. Black People: Entertainers of African Descent in Europe and Germany. Bonn: Bigit Lotz.

McGetrick, Maureen. 1980. “Black Patti Was a Success, Her Audience Was a Failure.” Providence Sunday Journal, September 28, 1980, 14. 
"Mme. Sissieretta Jones." Freeman (Indianapolis) 7, no. 18, May 4, 1895, 1. Readex: African American Newspapers.

Morrison, Matthew. 2019. "Race, Blacksound, and the Remaking of Musicological Discourse." Journal of the American Musicological Society 72, no. 3 (December): 781-823.

Rhode Island College. “Dr. Carl R. Gross Collection.” James P. Adams Digital Commons. https://digitalcommons.ric.edu/crgross papers/ (accessed January 31, 2020).

Stadler, Gustavus. 2010. "Never Heard Such a Thing: Lynching and Phonographic Modernity." Social Text 28 (1): 87-105.

Stoever, Jennifer L. 2016. Sonic Color Line: Race and the Cultural Politics of Listening in the U.S. New York: New York University Press.

Thurman, Kira. 2013. A History of Black Musicians in Germany and Austria, 1870-1961: Race, Performance, and Reception. Rochester: University of Rochester.

- 2019. "Performing Lieder, Hearing Race: Debating Blackness, Whiteness, and German Identity in Interwar Central Europe." Journal of the American Musicological Society 72, no. 3 (Fall): 825-65.

Van Vechten, Carl. 2000. Nigger Heaven. Introduction by Kathleen Pfeiffer. Urbana: University of Illinois Press.

Weheliye, Alexander G. 2005. Phonographies Grooves in Sonic Afro-modernity. Durham, NC: Duke University Press.

Weikart, Richard. 2004. From Darwin to Hitler: Evolutionary Ethics, Eugenics, and Racism in Germany. New York: Palgrave Macmillan.

Wells-Barnett, Ida B. 1895. A Red Record Tabulated Statistics and Alleged Causes of Lynchings in the United States, 1892-1893-1894. Chicago: Donohue \& Henneberry. Black Thought and Culture.

Wipplinger, Jonathan O. 2012. "Performing Race in Ernst Krenek's Jonny spielt auf." In Blackness in Opera, edited by Naomi André, Karen M. Bryan, and Eric Saylor, 236-59. Champaign: University of Illinois Press. 